Daria Banach

dariabanach2014@gmail.com

\title{
Aleksandra Skrzypek
}

\section{Problemy gospodarki leśnej w Lasku Wolskim Problems of forest management in Las Wolski}

\section{Streszczenie}

Las Wolski jest największą zieloną enklawą na terenie Krakowa. Historycznie dzieli się na dwa uroczyska: Las Wolski i Bielany. Zlokalizowane są tu 3 rezerwaty przyrody, na których terenie występują problemy z zarastaniem muraw kserotermicznych, a także z trwałością lasu. Obydwa zagrożenia mogą w przyszłości spowodować znaczne zmniejszenie wartości przyrodniczej terenu Lasu Wolskiego, dlatego bardzo ważne jest podjęcie odpowiednich działań.

Słowa kluczowe: Las Wolski, gospodarka leśna, trwałość lasu, murawy kserotermiczne, rezerwat przyrody

\section{Abstract}

Las Wolski constitutes the biggest green enclave in Cracow and belongs to the group of municipal forests. Historically, it is divided into two sections: Las Wolski and Bielany. In 1917, the first section, an area of 335.13 ha, was sold to the Municipal Savings Bank of Cracow; it was later gifted to the city. From that moment, Las Wolski adopted another name: Park Ludowy (The People's Park) and its primary function became recreational.

Keywords: Las Wolski, development of tree resources, recreation, nature reserve 


\section{WSTĘP}

Kompleks historycznie dzieli się na dwa uroczyska: Bielańskie i Wolskie. Najwcześniejsze informacje dotyczące tego terenu pochodzą z I połowy XIII w., kiedy to obszar w całości należał jeszcze do klasztoru Norbertanek. Jego nazwa, Las Wolski, pochodzi od nazwiska marszałka wielkiego koronnego Mikołaja z Podhajec Wolskiego. Pierwsze z uroczysk leży w południowo-zachodnim obrębie Lasu Wolskiego. Powstało ono w 1596 r., po wykupieniu części terenów lasu przez Sebastiana Lubomirskiego. Od 1605 r., aż po dzień dzisiejszy, należy do Klasztoru Braci Kamedułów. Na jego terenie znajduje się erema zakonu oraz rezerwat ścisły roślinności kserotermicznej ${ }^{1}$.

Drugie było własnością prywatną aż do 1917 r., kiedy to zostało sprzedane Kasie Oszczędności Miasta Krakowa, która ofiarowała park miastu. Zgodnie z Ustawą Rady Miejskiej leśna darowizna o powierzchni 335,15 ha, otrzymała miano „Parku Ludowego”. Teren ten stał się miejscem wycieczek mieszkańców Krakowa, swego rodzaju uzdrowiskiem dla możnych, którzy chronili się na dzikim terenie przed złym powietrzem oraz zarazami. Głównymi funkcjami lasu stały się rekreacja oraz turystyka. Zostało to silnie podkreślone w 1927 r., kiedy to w centrum kompleksu leśnego rozpoczęto budowę ogrodu zoologicznego. Las góruje nad miastem i jest wspaniałą, naturalną panoramą zieleni².

Teren ten wchodzi w skład kompleksu Bielańsko-Tynieckiego Parku Krajobrazowego. W jego obrębie występują trzy rezerwaty przyrody. W pierwszym z nich, Bielańskie Skały, objęte ochroną są murawy kserotermiczne, natomiast cały obszar drugiego, Panieńskie Skały, jest rezerwatem leśnym i krajobrazowym. Ostatni z nich, Przegorzalskie Skały - objęty jest ścisłą ochroną florystyczną.

W ciągu ostatnich 40 lat coraz bardziej zostaje zatracana funkcja rekreacyjno-wypoczynkowa na rzecz rezerwatów przyrody. Zostały zaniedbane podstawowe zabiegi prowadzone normalnie w lasach i przyroda zostaje pozostawiona sama sobie. Przy pielęgnacji drzewostanu stosuje się wyłącznie cięcia sanitarne, co doprowadziło do degradacji obszarów cennych przyrodniczo, poprzez inwazyjne rozprzestrzenianie się samosiewów różnych gatunków drzew $^{3}$. Taka gospodarka doprowadziła do stopniowego zagęszczania się lasu i hamowania rozwoju tej najważniejszej funkcji, która była ideą całego założenia, czyli funkcji rekreacyjnej.

Należy podkreślić wartość obszaru wynikającą z wieloletniej tradycji i przywiązania mieszkańców Krakowa i okolic do tego miejsca wykorzystywanego przed wszystkim rekreacyjnie. Teren ten od dawna był miejscem bardzo ważnym dla krakowian. Wiąże się z nim mnóstwo historii, zarówno wielkich, którym nadano miano legend, jak i tych mniejszych, prozaicznych, które sprawiły, że teren ten jest tak bliski sercu mieszkańcom Krakowa. Wiele osób wiąże Las Wolski ze swoim dzieciństwem, pierwszymi randkami, ale też z pierwszymi spotkaniami z dziką przyrodą - rodzimą florą i egzotyczną fauną (Ogród Zoologiczny w Krakowie).

Warto więc zastanowić się nad obecnie prowadzonymi zabiegami gospodarki leśnej tego miejsca, aby zachować je w jak najlepszym stanie dla kolejnych pokoleń. Ideą trwale 
zrównoważonej gospodarki jest to, aby ekosystemy leśne mogły spełniać różnorodne funk$\mathrm{cje}^{4}$. Las Wolski wchodzi w skład większej struktury jaką są Lasy Państwowe, które od wielu lat kształtują już swój wielofunkcyjny charakter. Dlatego też dostosowanie odpowiednich zabiegów jest wysoce istotne, aby omawiany obszar wpisał się w ogólnie przyjęte standardy.

\section{CEL I METODY BADAŃ}

Celem pracy było zwrócenie uwagi na główne problemy gospodarki leśnej na terenie Lasku Wolskiego, związane z nieprawidłowo prowadzonymi dotychczasowymi działaniami w strukturze drzewostanu i poszycia leśnego. Najważniejszym aspektem było jednak znalezienie rozwiązań wzorowanych na metodach stosowanych w innych Lasach Państwowych na terenie Polski, których pozytywne efekty można aktualnie obserwować.

Skupiono się głównie na metodach badań studialnych polegających na analizie artykułów, książek tematycznych zajmujących się analizami Lasu Wolskiego, zarówno od strony funkcjonowania ekosystemów ${ }^{5}$, jak i prowadzonej tam turystyki ${ }^{6}$ oraz analizach kondycji i struktury wiekowej drzewostanu ${ }^{7}$. Dodatkowo prowadzono również własne obserwacje terenowe ma podstawie zdobytej wiedzy.

Wszystkie wykorzystane pomoce dały podstawy do przeprowadzenia wnikliwej analizy stanu obecnego pod względem gospodarki leśnej jak i oczekiwanej wielofunkcyjności terenu. Następnie skupiono się na wykorzystaniu dostępnych źródeł w celu pozyskania wiadomości na temat ogólnych zasad działań prowadzonych w Lasach Państwowych, stanowiących wzór, do którego należałoby dążyć przy kształtowaniu i utrzymywaniu Lasu Wolskiego.

\section{STAN OBECNY - UWARUNKOWANIA PRZYRODNICZE TERENU. FLORA I FAUNA}

W Lasku Wolskim występuje podział na tereny leśne oraz przedpole tworzące naturalną otulinę dla lasu. Tereny te są bardzo cenne przyrodniczo nie tylko dla miasta Krakowa, ale także dla całego kraju. Praktycznie wszystkie zbiorowiska leśne oraz fragmenty z roślinnością kserotermiczną, występujące w granicach tego terenu, zakwalifikowane zostały do obszarów o najwyższych walorach przyrodniczych. Do wysoko cenionych zaliczono Ogród Zoologiczny, polany leśne oraz niewielkie fragmenty w otoczeniu Willi Decjusza i zabudowań Uniwersytetu Jagiellońskiej. Najbardziej wartościowymi zbiorowiskami są tutaj wartościowe zbiorowiska kserotermiczne, które są bardzo bogate zarówno florystycznie, jak i pod względem różnorodności występującej fauny. Również tereny leśne są zróżnicowane i posiadają wysokie walory przyrodnicze. Spotykamy tutaj głównie drzewostany składające się z dębu (Quercus sp.), buka (Fagus sp.) i brzozy (Betula sp.), ale można spotkać też rzadkie gatunki drzew takie jak lipa srebrzysta (Tilia tomentosa) czy sosna smołowa (Pinus rigida) ${ }^{8}$. 
Te cechy środowiska pozwoliły zakwalifikować oraz objąć ochroną obszar Lasu Wolskiego w ramach Bielańsko-Tynieckiego Parku Krajobrazowego. Dodatkowo w jego granicach zlokalizowano 3 rezerwaty: Bielańskie Skałki i Skałki Przegorzalskie oraz Panieńskie Skały. Dwa pierwsze, założone w latach 50. XX wieku, o powierzchni kolejno 1,73 ha i 1,38 ha, obejmują ścisłą ochroną małe, skaliste zbocza porośnięte murawami kserotermicznymi, w skład których wchodzą rośliny np. oman szorstki (Inula hirta), bodziszek czerwony (Geranium sanguineum) oraz ogólnie pojętej fauny tam występującej. Panieńskie Skały stanowią rezerwat częściowy - leśny i krajobrazowy założony w 1953 r. o powierzchni 6,41 ha. Obejmuje on ochroną wąwozy w skałach wapiennych porośnięte lasem bukowym z domieszką dębu (Quercus sp.), sosny (Pinus sp.), grabu (Carpinus sp.) i jaworu (Acer pseudoplatanus), stanowiącymi 150-letni drzewostan'.

Duży wpływ na jakość i zróżnicowanie tych zbiorowisk ma ukształtowanie terenu, występujące tu żyzne gleby, a także mikroklimat stworzony przez inne rośliny. Wiąże się to jednak z pewnymi trudnościami, które trzeba brać pod uwagę przy gospodarowaniu niniejszego obszaru. Jednym z nich jest fakt, że gleby, szczególnie te rozwinięte na lessach, wymagają szczególnej ochrony. Największym problemem jest erozja wodna, w wyniku której ulegają wypłukaniu elementy organiczne, znacznie zmniejszające urodzajność gleb, a co za tym idzie bogactwo roślinności tam występującej ${ }^{10}$.

Warto wspomnieć także o niezwykłej roli jaką to miejsce pełni dla różnorodności gatunkowej zwierząt. Jako że Las Wolski pozostaje w strefie przenikania się ekosystemów, tzw. strefie ekotonowej, wpływa to na występowanie gatunków zwierzyny leśnej, łąkowej oraz gatunków pospolitych towarzyszących występujących w przestrzeniach miejskich.

\subsection{PROBLEMY ZAGOSPODAROWANIA}

Jednym z podstawowych problemów, z jakim Las Wolski boryka się od kilkunastu lat, jest niedostosowanie zabiegów gospodarki leśnej do wieku drzewostanu, co prowadzi między innymi do zatracania funkcji rekreacyjnej na tym obszarze. Zauważalny staje się niepokojący proces przeistaczania się całego obszaru, nawet terenów przeznaczonych do użytku publicznego, w obszary przypominające swoim wyglądem rezerwat. Gospodarka leśna prowadzona na terenie Lasu Wolskiego od około 40 lat ogranicza się jedynie do cięć pielęgnacyjnych i sanitarnych ${ }^{11}$. Problemy rozwiązywane są na poziomie bezpieczeństwa, a cały drzewostan, łącznie z grupami samosiewów w podszycie, pozostaje nienaruszony. Wygląda to tak, jakby pierwotna funkcja powoli się rozmywała na rzecz ochrony całego drzewostanu. Występuje tutaj wiele pięknych, wieloletnich okazów drzew, które przy tak gęstym podszycie, nie mogą zostać zauważone, gdyż dostęp do nich jest utrudniony. Na podstawie badań przeprowadzonych przez R. Zygmunta, J. Banasia i S. Ziębę oraz opisanych w artykule Trwałość lasów miejskich na przykładzie „Lasu Wolskiego" w Krakowie można zauważyć, że na tym terenie brak jest wyraźnych różnic, jakie powinny występować między różnymi fazami rozwoju lasu. Takie wyniki sprawiły, że aby móc 
opisać strukturę lasu, należało wprowadzić nową klasyfikację drzewostanu. Wyróżnikiem stały się kategorie grubości drzew: drzewa cienkie i średnie o pierśnicy 7-34 cm, drzewa grube 35-54 cm oraz drzewa bardzo grube o pierśnicy równej lub większej niż 55 cm (Suchecki 1947, Rutkowski 1989, Jaworski 1990, Przybylska i inni 2006) $)^{12}$.

W Lesie Wolskim prowadzone zabiegi ograniczały się w ciągu ostatnich 40 lat niemal wyłącznie do cięć sanitarnych, aby nie czynić wizualnych uszczerbków w szacie leśnej. Jednym z głównych celów takich prowadzenia takich działań było zmniejszenie ryzyka nieszczęśliwego wypadku na skutek przewracania się drzew lub obłamywania konarów. W wyniku ograniczenia cięć użytkowania rębnego zatarły się różnice między drzewostanami w fazie terminalnej i w fazie optymalnej, a dawny podział na te fazy nie ma obecnie znaczenia dla charakterystyki stanu zasobów drzewnych. Wprowadzony ponad 30 lat temu podział lasu na fazy rozwojowe nie odzwierciedla obecnego stanu lasu' ${ }^{13}$.

W ciągu minionych 30 lat można było pozwolić na niski odsetek cięć z powodu stosunkowo dużego udziału drzew cieńszych i średnich klas grubości, zwłaszcza w odniesieniu do dębu (Quercus sp.) i buka (Fagus sp.), których naturalny kres odsunięty był znacznie w czasie. Obecnie struktura drzewostanów przesunięta jest w kierunku grubości maksymalnych, jakich mogą dożyć te dwa główne gatunki drzew. Wydaje się więc nieuniknione nasilenie się procesów ich ubywania w porównaniu z poprzednimi okresami gospodarczymi. Wynikają z tego poważne problemy z ustaleniem działań, które pomogłyby zoptymalizować urządzeniowo-hodowlane oraz inżynieryjne zagospodarowanie tego terenu. Jest to istotne również dlatego, iż jest to jeden z najbardziej znanych lasów miejskich. Tego typu odstąpienie od odpowiednio dostosowanej i systematycznie prowadzonej gospodarki doprowadziło do tego, iż wiele ścieżek prowadzących przez las pozarastało. To samo zaczyna też dziać się z polanami wypoczynkowymi. Jednakże dzięki odpowiedniej gospodarce, prowadzonej systematycznie, nie ma sytuacji takich, aby w lesie panował nieporządek. Utrzymywany jest tam ład i czystość.

Problem stanowi również zarastanie cennych muraw kserotermicznych przez rośliny inwazyjne dla tych terenów. W tym aspekcie spadek odporności środowiska może być spowodowany brakiem oddziaływań antropogenicznych, a także oddaleniem od innych terenów o podobnym potencjale przyrodniczym. Brak tradycyjnej gospodarki uruchamia procesy sukcesji ekologicznej, co może prowadzić do przekształcenia muraw w ciepłe zarośla i lasy a następnie do zanikania roślinności kserotermicznej. Jest to rezerwat ścisły, na terenie którego jakakolwiek ingerencja ludzi jest niedopuszczalna. Wskutek intensywnej sukcesji gatunków drzewiastych, która nastąpiła w latach 70., zbiorowiska ciepłolubne stopniowo kurczyły się, sukcesywnie ze składu gatunkowego wypadały najcenniejsze, najwrażliwsze elementy ${ }^{14}$. Ochrona rezerwatowa doprowadziła do tego, że zespoły murawowe i naskalne zajmują jedynie kilkanaście procent rezerwatu i w dużej mierze są już silnie przekształcone ${ }^{15}$. Mimo przeprowadzonych w 1991 r. zabiegów odkrzewiania, murawy zostały opanowane przez krzewy oraz drzewa i całkowicie zanikły. To samo od kilku lat ma miejsce również w zbiorowiskach 
zarośli kserotermicznych, które w ostatnich dziesięcioleciach zostały w większości zajęte przez las. W odnowieniach gatunkiem dominującym jak również najbardziej ekspansywnym jest jesion (Fraxinus sp.), w mniejszym stopniu lipa (Tilia sp.) i jawor (Acer pseudoplatanus) ${ }^{16}$. Naturalna sukcesja jest na tym terenie zagrożeniem, które może mieć wpływ na przyszłą strukturą środowiska. Proces ten zwrócony w kierunku zbiorowisk leśnych może spowodować zanik zbiorowisk kserotermicznych, utraty wartościowych powiązań widokowych jak również zasobów świata zwierząt związanych z siedliskami nieleśnymi.

Obserwowane etapy sukcesji ( w kolejności od najwcześniejszego): (1) kserotermiczna murawa Koelerio-Festucetum sulcatae - (2) ciepłolubne zarośla Peucedano cervariae-Coryletum - (3) ciepłolubny podzespół grądu subkontynentalnego Tilio-Carpinetum melittetosum. Mimo tego, na terenie rezerwatu nadal występują liczne okazy roślin ciepłolubnych m.in. ożota zwyczajna (Linosyris vulgaris), krwawnik pannoński (Achillea pannonica), dzwonek syberyjski (Campanula sibirica), turzyca Michaela (Carex michelii) czy przetacznik kłosowy (Veronica spicata $)^{17}$.

\subsection{PROPOZYCJE ROZWIAZZAŃ PROBLEMU}

Na podstawie przeanalizowanej literatury przedmiotu można zaproponować kilka rozwiązać mających na celu poprawę stanu obszarów chronionych i zachowania ich wartości przyrodniczej i kulturalnej. Jednym z najważniejszych działań, które należało by powziąć na samym początku, powinno być stopniowe dostosowywanie gospodarki leśnej do wieku drzew i ich zagęszczenia. W przypadku ochrony lasów bardzo często zarzucane są wycinki nawet pojedynczych okazów drzew, aby drzewostan nie został naruszony. Niestety powoduje to działanie odwrotne, a mianowicie zmniejsza trwałość lasu i może poważnie zaważyć na jego istnieniu w przyszłości. Poznański trwałość lasu definiuje jako dynamiczny stan równowagi pomiędzy procesami: odnawiania, przeżywania i ubywania drzew i drzewostanów na płaszczyźnie gospodarstwa leśnego ${ }^{18}$. Z definicji tej wynika, że wszystkie te procesy są potrzebne, aby las zachował wszystkie walory, a więc należałoby z powrotem wprowadzić do gospodarki leśnej Lasu Wolskiego cięcia pobierania plonu. Istota utrzymania trwałości istnienia i ochrony lasu tkwi zatem nie w zakazie użytkowania i w biernej ochronie, ale w regulowanej przez człowieka relacji pomiędzy wzajemnie ze sobą powiązanymi trzema procesami biologicznymi ${ }^{19}$.

Innym bardzo istotnym problemem jest zarastanie muraw kserotermicznych. Podjęcie działań w tym kierunku jest o tyle istotne, że to właśnie one zdecydowały o utworzeniu rezerwatu Bielańskie Skały, a przez nieskuteczne dotychczasowe działania mogą one zostać zastąpione innymi, mniej cennymi zbiorowiskami roślinnymi. Jedną z najbardziej dotkliwych zmian dla muraw było porzucenie ekstensywnego wypasu, dzięki któremu zatrzymywana była sukcesja naturalna prowadząca do ich przeistaczania się w zbiorowiska leśne i zaroślowe. W dzisiejszych czasach w ramach ochrony wypas, najczęściej owiec i kóz, jest coraz 
częściej przywracany. Przykładem takiego działania może być projekt „Utrzymanie bioróżnorodności siedlisk kserotermicznych w Małopolsce” realizowany przez Regionalną Dyrekcję Ochrony Środowiska w Krakowie, która stara się przywrócić tradycje pasterskie na ciepłolubnych łąkach Miechowszczyzny ${ }^{20}$. W ramach prowadzonych działań zakupiono stado 10 owiec olkuskich, a do ich wypasu zachęcono społeczność lokalną. Jako, że nie wszędzie jest możliwe przywrócenie takich tradycji, sposobem zastępczym może być karczowanie, cięcia prześwietlające zarośla i usuwanie gatunków inwazyjnych z terenów muraw. Działania tego typu muszą być przeprowadzane systematycznie, aby nie dopuścić do momentu, gdy murawy będą już zbytnio przekształcone, aby przywrócić im ich oryginalny charakter.

\section{PODSUMOWANIE}

Omawiany teren jest bardzo bogaty oraz złożony pod względem biologicznym. W jego obrębie praktycznie nie występują tereny zdegradowane, co jest rzadkością dla obszarów zielonych w pobliżu dużych miast. Są to tereny ważne nie tylko przyrodniczo, ale także rekreacyjnie i wypoczynkowo, dlatego bardzo istotną sprawą jest, aby umiejętnie połączyć funkcje ochronne z turystycznymi. Nie można dopuścić do zdegradowania przyrody na tym obszarze, jednocześnie jednak należy udostępnić las do użytku mieszkańcom Krakowa i okolic. Spełnianie przez las funkcji ochronnych i społecznych nie musi oznaczać zakazu ich użytkowania, jeżeli tylko ustalony rozmiar użytkowania nie zagraża utracie jego trwałości. Użytkowanie zasobów drzewnych jest więc narzędziem ochrony i utrzymania trwałości istnienia, a nie niszczenia przyrody w lasach ${ }^{21}$. Istotne jest także, aby pamiętać, że wszelkie zmiany, pozytywne i negatywne, będą obserwowane i oceniane nie tylko przez krakowian, ale także przez szerokie grono zainteresowanych. W związku z tym wszystkie działania podjęte na tym terenie muszą być przemyślane i odpowiednio uzasadnione, aby teren mógł wciąż pozostać użytkowany przez następne pokolenia bez straty na jego wartości przyrodniczej i kulturalnej. 


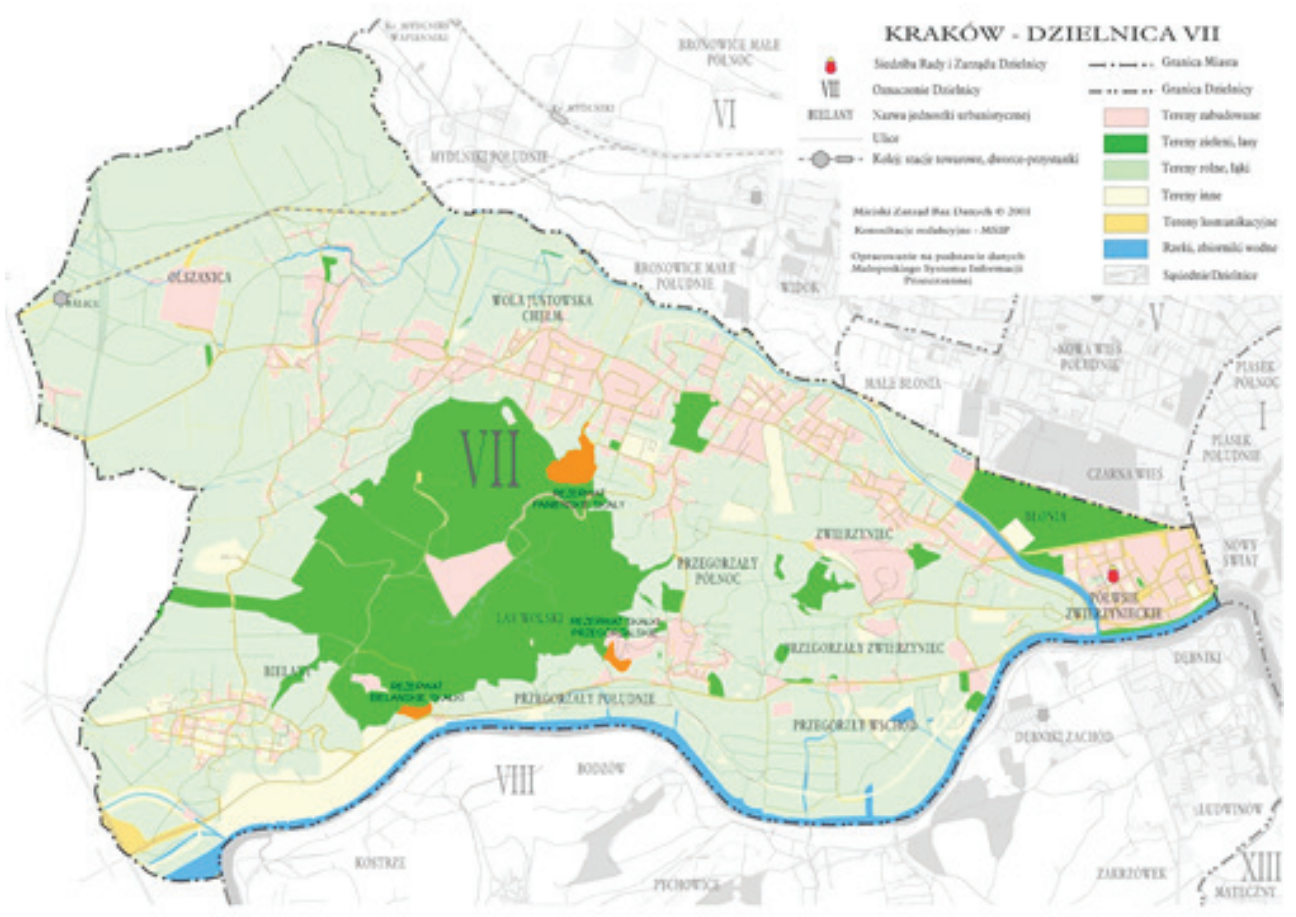

II. 1. Mapa dzielnicy z zaznaczonymi rezerwatami

Źródło: opracowanie własne na podstawie mapki: http://nowy.dzielnica7.krakow.pl/wp-content/ uploads/2017/06/mapa_krakow_dzielnica_vii.jpg, dostęp: 26.11.2018. 


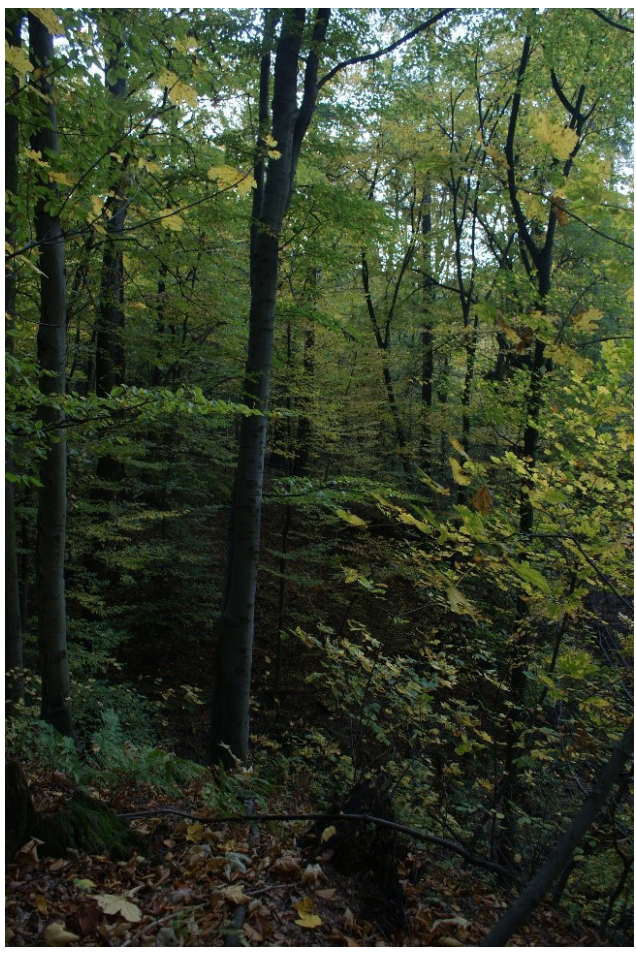

II. 2. Widok z leśnej ścieżki, , Aleksandra Skrzypek (05.11.2018)

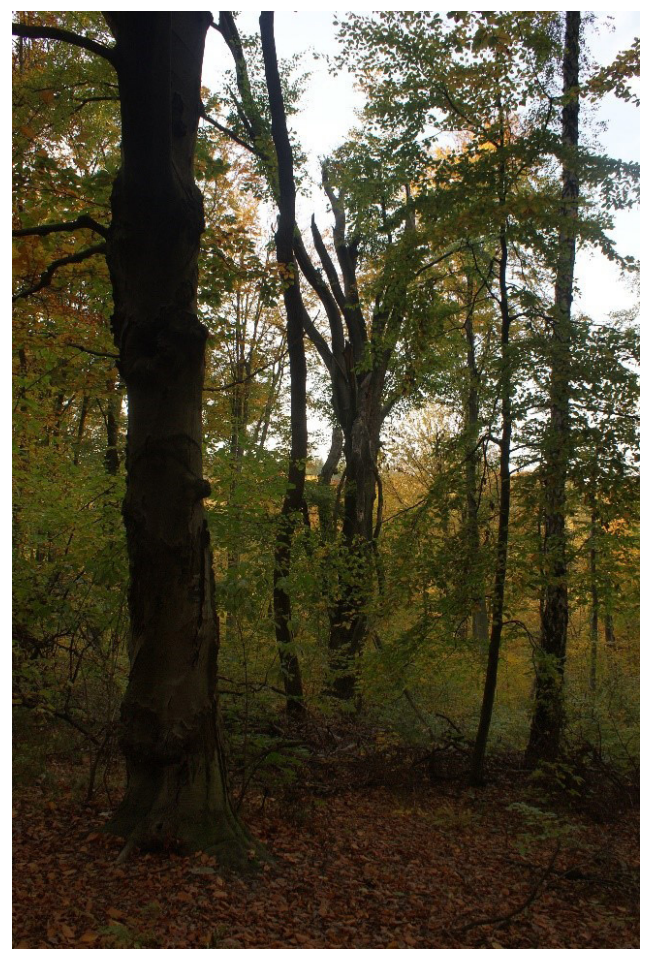

II. 3. Widok ze ścieżki prowadzącej do ZOO, Aleksandra Skrzypek (05.11.2018) 


\section{PRZYPISY}

1 J. Skotnicki, Las Wolski. Przewodnik, Copyright by Józef Skotnicki, Kraków 2002 r., konsultacje naukowe doc. Dr hab. Kazimierz Gądek - Zakład Ochrony Lasu Akademii Rolniczej im. H. Kołłątaja w Krakowie, rozdział Historia, s. 5-12.

2 Ibidem

3 Urząd Miasta Krakowa, Biuro Planowania Przestrzennego Oddział Planowania Przestrzennego Pracownia Urbanistyczna, MIEJSCOWY PLAN ZAGOSPODAROWANIA PRZESTRZENNEGO „LAS WOLSKI” PROGNOZA ODDZIAŁYWANIA NA ŚRODOWISKO, Kraków, październik 2008 r. aktualizacja, kwiecień 2009 r., rozdział 5.4. Ocena zagrożeń dla środowiska, s. 9, 40.

4 Plan Regionalnej Dyrekcji Ochrony Środowiska w Krakowie, Ochrona muraw kserotermicznych w Małopolsce, dostęp: 8.01.2013.

5 Ibidem, także: Urząd Miasta Krakowa, op. cit.; W. Milewski (red.), Lasy w Polsce 2017, Centrum Informacyjne Lasów Państwowych, Warszawa 2017, rozdział Funkcje lasu, s. 19; R. Zygmunt, J. Banaś, S. Zięba, Trwałość lasów miejskich na przykładzie "Lasu Wolskiego" w Krakowie, Studia i Materiały CEPL w Rogowie, r. 16. Zeszyt 39/2A/2014.

6 J. Skotnicki, op. cit.; Skarby przyrody i kultury Krakowa i okolic. Ekologiczne ścieżki edukacyjne, Instytut Ochrony Przyrody PAN, Instytut Studiów Franciszkańskich WT PAT, Instytut Nauk o Środowisku UJ i Wydawnictwo WAM, Kraków 2005, rozdział III, s. 114-117.

7 W. Milewski (red.), op. cit.

8 J. Skotnicki, op. cit.

9 Ibidem.

10 Ibidem.

${ }^{11}$ R. Zygmunt, J. Banaś, S. Zięba, op. cit.

12 Ibidem.

13 Ibidem.

${ }^{14}$ Urząd Miasta Krakowa, op. cit.

15 Plan Regionalnej Dyrekcji Ochrony Środowiska w Krakowie, Ochrona muraw kserotermicznych w Małopolsce, dostęp 8.01.2013.

${ }^{16}$ Urząd Miasta Krakowa, op. cit.

17 Skarby przyrody i kultury Krakowa i okolic, op. cit.

18 R. Poznański, Trwałość lasu i regulacja a ochrona przyrody w lasach, Studia i Materiały CEPL w Rogowie R. 6, Zeszyt 39/2A/2014, s. 55-58.

19 Ibidem.

20 Plan Regionalnej Dyrekcji Ochrony Środowiska w Krakowie, op. cit.

${ }^{21}$ R. Poznański, op. cit. 


\section{BIBLIOGRAFIA}

Skotnicki J., Las Wolski. Przewodnik, Kraków 2002 r., konsultacje naukowe doc. Dr hab. Kazimierz Gądek - Zakład Ochrony Lasu Akademii Rolniczej im. H.Kołłątaja w Krakowie, rozdział Historia.

Skarby przyrody i kultury Krakowa i okolic. Ekologiczne ścieżki edukacyjne, Instytut Ochrony Przyrody PAN, Instytut Studiów Franciszkańskich WT PAT, Instytut Nauk o Środowisku UJ i Wydawnictwo WAM, Kraków 2005, rozdział III.

Urząd Miasta Krakowa, Biuro Planowania Przestrzennego Oddział Planowania Przestrzennego Pracownia Urbanistyczna, MIEJSCOWY PLAN ZAGOSPODAROWANIA PRZESTRZENNEGO "LAS WOLSKI" PROGNOZA ODDZIAŁYWANIA NA ŚRODOWISKO, Kraków, październik 2008 r. aktualizacja, kwiecień 2009, rozdział 5.4. Ocena zagrożeń dla środowiska.

Plan Regionalnej Dyrekcji Ochrony Środowiska w Krakowie, Ochrona muraw kserotermicznych w Małopolsce, dostęp 8.01.2013.

Milewski W. (red.), Lasy w Polsce 2017, Centrum Informacyjne Lasów Państwowych, Warszawa 2017, rozdział Funkcje lasu.

Zygmunt R., Banaś J., Zięba S., Trwałość lasów miejskich na przykładzie "Lasu Wolskiego" w Krakowie, Studia i Materiały CEPL w Rogowie, R. 16, Zeszyt 39/2A/2014.

Poznański R., Trwałość lasu i regulacja a ochrona przyrody w lasach, Studia i Materiały CEPL w Rogowie, R. 6, Zeszyt 39/2A/2014. 